\title{
KESIAPAN KESATUAN AKSI MAHASISWA MUSLIM INDONESIA (KAMMI) DALAM MENGHADAPI ERA MASYARAKAT EKONOMI ASEAN DI KOTA MEDAN
}

\author{
Alimul Hadi, Erlina, Agus Suriadi \\ Program Studi Perencanaan Pembangunan Wilayah dan Pedesaan \\ SekolahPasca Sarjana Universitas Sumatera Utara \\ alimulhadi@gmail.com
}

\begin{abstract}
Abstrak
Penelitian ini bertujuan untuk Melihat dan meneliti kesiapan Kesatuan Aksi Mahasiswa Muslim Indonesia Kota Medan dari faktor internal maupun faktor eksternal dalam menghadapi Era Masyarakat Ekonomi Asean. Jenis penelitian ini adalah penelitian kualitatif perspektif fenomenologi sosial yang dimaksudkan untuk mengungkapkan secara rinci fenomena kesiapan Kesatuan Aksi Mahasiswa Muslim Indonesia Kota Medan dan tantangannya terhadap MEA. Dari hasil Penelitina yang dilakukan Penulis menympulkan bahwa dalam hal ini Kesatuan Aksi Mahasiswa Muslim Indonesia Kodta Medan Belum Sepenuhnya siap dalam menghadapi era Masyarakat Ekonomi Asean.Persiapan KAMMI menghadapi MEA dilakukan harusnya dilakukakn dengan mengevaluasi kegiatan yang pernah mereka lakukan. Kegiatan-kegiatan yang bersifat pengembangan diri terutama dalam hal pengembangan skill dan kewirausahaan harus menjadi titik fokus. Hal ini dapat dilakukan dengan memberikan follow up terhadap kegiatan pengembangan dilri yang sudah dilakukan tersebut. Seperti memberikan pengembangan usaha bagi para kader, ataupun memberikan fasilitas bagi kader yang ingin mengembangkan bakat menulis seperti klub menulis ataupun media.
\end{abstract}

Kata Kunci: Kesiapan, Kammi, Masayarakat Ekonomi Asean

\section{PENDAHULUAN}

Pengaruh gelombang arus globalisasi memaksa negara-negara berkembang untuk memperbaiki diri. Jika tidak, Negara tersebut akan runtuh sebab tujuan dari globalisasi adalah untuk mendorong pertumbuhan perekonomian suatu negara, meningkatkan pembangunan yang merata serta mengurangi tingkat kemiskinan dan pengangguran. Adapun yang menjadi pengikut globalisasi hampir meliputi seluruh bangsa dan negara didunia ini. Dalam globalisasi, yang lemah akan dikuasai oleh yang kuat dalam setiap lini aspek kehidupan bernegara. Dengan kata 
lain negara yang berkembang telah bergantung kepada negara yang maju. Jika negara yang maju tidak memberikan bantuannya, negara-negara yang berkembang tadi semakin miskin, sedangkan negara yang maju semakin kaya. Mulai dari aspek ekonominya, keamanannya, dan sosial budaya termasuk pendidikan dalam suatu bangsa.

Salah satu contoh pelaksanaan globalisasi adanya perdagangan bebas antar berbagai negara atau antar benua. Di Eropa dikenal dengan EEC (European Economic Community) atau Masyarakat Ekonomi Eropa. Adapun negara-negara yang menjadi anggota MEE adalah: Belanda, Belgia, Denmark, Inggris, Irlandia, Jerman, Luxemburg, Prancis, Yunani, dan Italia yang berlangsung pada 1 Januari 1958. NAFTA (North America Free Trade Agreement), negara yang termasuk ialah Amerika Serikat, Kanada dan Meksiko pada tahun 1 Januari 1994. Dan sekarang dibagian Asia Tenggara, yaitu AEC (Asean Economic Community) berlangsung 1 Januari 2016. Bisa dikatakan Eropa dan Amerika adalah negara senior dalam melaksanakan perdagangan bebas antar berbagai negara. Sebab mereka lebih dahulu menjalankannya. Sedangkan Indonesia adalah juniornya yang terkena dampak gelombang globalisasi.

KAMMI sebagai wadah organisasi kemahasiswaan dan berbasis di kampus tentu memiliki tanggung jawab terhadap masyarakat dan bangsa. Kaum mahasiswa yang identik dengan kecerdasan cara berfikir dan ilmu pengetahuan yang luas tentunya harus memiliki peran aktif di masyarakat terutama mempersiapkan diri menghadapi Globalisasi yang adalam hal ini Era Masyarakat Ekonomi Asean. KAMMI yang mempunyai visi perjuangan panjang adalah bagaimana menciptakan pemimpin pemimpin ummat dan bangsa tentunya di tuntut untuk memiliki kualitas sumber daya manusia yang tinggi. Peningkatan sumber daya manusia juga harus dilakukan melalui pelatihan dan pengkaderan untuk didik menjadi seorang pemimpin. KAMMI yang berideologi dan berpahaman bahwa Islam menjadi dasar berpijakan dalam berorganisasi tentu nya yang dituntut sumber daya manusia yang memiliki kemampuan akademisi yang baik, aktif dimasyarakat dan berkarakter menjaga nilai nilai yang islami. 
Olehkarenanya pengkaderan dan pelatihan yang terstruktur rapi dan berjenjang diharapkan mampu menghasilkan kualitas sumber daya yang di harapkan.

Berdasarkan latar belakang masalah di atas, maka permasalahan dalam penelitian ini adalah bagaimana Kesiapan Kesatuan Aksi Mahasiswa Muslim Indonesia (KAMMI) dalam menghadapi Era Masyarakat Ekonomi Asean di Kota Medan. Tujuan penelitian ini adalah Melihat dan meneliti kesiapan Kesatuan Aksi Mahasiswa Muslim Indonesia Kota Medan dari faktor internal maupun faktor eksternal dalam menghadapi Era Masyarakat Ekonomi Asean

Penelitian terdahulu yang berkaitan antara lain tentang Kesiapan Organisasi dalam Menghadapi Implementasi Jaminan Kesehatan Nasional (JKN) dengan Menggunakan Analisis SWOT di RSUD Cut Meutia Lhokseumawe, Kabupaten Aceh Utara. Hasil analisis penelitian menunjukkan bahwa RSUD Cutmutia Lhokseumawe harus punya strategi terbaik yang dalam hal ini antara lain pengoptimalan pelayanan, penguatan jaringan, peningkatan upaya promsi, peningkatan kwalitas SDM dengan kesempatan pendidikan dan pelatihan, dengan demikian RSUD Cut Meutia Lhokseumawe akan siap mengimplementasikan JKN.

\section{Masyarakat Ekonomi Asean}

Nizar (2014), Paling tidak terdapat tiga gelombang integrasi regional sejak General Agreement on Tariff and Trade (GATT) disepakati pada tahun 1947. Gelombang pertama adalah integrasi regional Eropa di tahun 70-an yang menempatkan Eropa sebagai aktor utama dalam perdagangan global. Gelombang kedua dipicu oleh ketidakpuasan Amerika terhadap prinsip non diskriminasi dalam GATT yang bermuara pada pembentukan North American Free Trade Agreement (NAFTA) di awal era 90-an. Gelombang ketiga adalah diinisiasi oleh negara-negara Asia dengan memperkenalkan preferensi tarif seperti Economic Cooperation Organization (ECO), South Asian Association for Regional Cooperation (SAARC), dan Association of South-East Asian Nation (ASEAN).

Arifin (2007), langkah ASEAN diatas sejalan dengan tuntutan global yang ditandai dengan semakin menjamurnya bentuk integrasi keuangan dan ekonomi di 
berbagai kawasan. Sebut misalnya Eropa, integrasi regionalnya diawali dengan integrasi ekonomi (sektor riil) yang kemudian diikuti dengan integrasi moneter dan diakhiri dengan pembentukan mata uang Euro. Di kawasan Afrika juga memiliki institusi regional (CFA Franc Zone dan Gulf Area) yang bertugas mengintegrasikan ekonomi di kawasan tersebut dengan membentuk dan menggunakan mata uang bersama. Artinya, meskipun di kawasan Asia Tenggara belum dimunculkan mata uang bersama, namun ASEAN sebagai leading sector bentuk integrasi di kawasan, melakukan upaya kesepakatan-kesepakatan, diantaranya Komunitas ASEAN 2015 (ASEAN Community 2015).

Hakim (2013), ASEAN Declaration, Bangkok, 08 Agustus 1967, memutuskan bahwa kawasan Asia Tenggara memiliki organisasi regional yang bernama ASEAN. Dengan fokus pada isu keamanan dan perdamaian di kawasan Asia Tenggara. Dimulai dari lima negara pendiri, yakni Indonesia, Filipina, Malaysia, Singapura dan Thailand, kini ASEAN terdiri dari sepuluh Negara yang bergabung kemudian, yakni Brunai Darussalam (1984), Vietnam (1995), Myanmar dan Laos (1997), serta Kamboja (1999).

Komunitas ASEAN 2015 (ASEAN Community 2015) adalah suatu kesepakatan tentang pembentukan komunitas yang terdiri dari tiga pilar, yakni Masyarakat Ekonomi ASEAN (ASEAN Economic Community), Masyarakat Keamanan ASEAN (ASEAN Security Community) dan Masyarakat SosialBudaya ASEAN (ASEAN Socio-cultural Community).

\section{Pemuda}

Menurut UU kepemudaan nomor 40 tahun 2009, pemuda adalah mereka yang berusia 16 tahun hingga 30 tahun, Sejarah membuktikan bahwa pemuda berperan penting dalam kemerdekaan dimana saja, dinegara mana saja kemerdekaan tidak pernah luput dari peran serta pemuda. Karena pemudalah memiliki semangat dan ambisius yang tinggi dalam mencapai keinginannya, memperjuangkan, mempertahankan perubahan kearah yang lebih baik. Pemuda memiliki banyak potensi yang tertanam dalam dirinya, pemuda harus berani bermimpi dan bercita-cita setinggi-tingginya. 
Sedangkan menurut Thahan (2002), Pemuda selalu berada di garis terdepan dalam perjuangan ummat dan mampu terlibat di semua sektor, yaitu:

1. Sektor Pembebasan dan Kemerdekaan

Pemuda adalah kemampuan, tekad, keberanian, dan kesabaran menghadapi tantangan. Dengannya ummat menghalau musuh dan mengangkat bendera kejayaannya.

2. Sektor Pemikiran dan Pembentukannya

Pemuda adalah unsur kokoh yang mampu belajar keras, menguasai dan menghasilkan pemikiran serta pembaruan. Ibarat ranting yang masih segar, kelenturannya cukup untuk terbentuknya pemikiran sekaligus mentransformasikan pemikiran tersebut kepada orang lain.

3. Sektor Iman dan Amal

Iman yang diam dan kehilangan dinamika tidak ada harganya, sedangkan keimanan pemuda selalu memunculkan energi tersembunyi yang besar dalam bentuk gerakan membina ummat.

4. Sektor Perubahan

Pemuda adalah pelopor dan sarana perubahan. Allah Suhhanahu wata'ala tidak akan mengubah nasib suatu kaum sampai mereka mengubah kondisi jiwa mereka. Sedangkan pemuda memiliki kekuatan jiwa yang besar, maka perubahan yang dilakukannya pun besar.

Pemuda merupakan aset bangsa yang akan melanjutkan estafet pembangunan bangsa dimasa yang akan datang. Pemuda memiliki dinamisasi dan semangat yang tinggi dalam berbagai aspek dimasyarakat, pemuda dapat lebih diterima dilingkungannya jika membawa suasana-suasana kebaikan dan mengarah pada perubahan, perubahan yang diharapan sesuai dengan apa yang diharapkan oleh masyarakat. Semangat yang tinggi dan ide-ide memberikan peran kepada pemuda dalam setiap sektor kehidupan. 


\section{Kesatuan Aksi Mahasiswa Muslim Indonesia}

Kualitas suatu bangsa bisa dilihat dari kualitas pemudanya, karena generasi muda adalah penerus dan pewaris bangsa di masa yang akan datang. Generasi muda harus mempunyai karakter dan disiplin yang kuat untuk membangun bangsa dan negaranya, memiliki kepribadian tinggi, semangat nasionalisme, pantang menyerah, mampu memahami pengetahuan dan teknologi untuk bersaing secara global.

Pengertian mahasiswa menurut Kamus Besar Bahasa Indonesia (KBBI) mahasiswa ialah pelajar perguruan tinggi. Didalam struktur pendidikan Indonesia,mahasiswa menduduki jenjang satuan pendidikan tertinggi di antara yang lain. Sedangkan menurut (Sarwono 1978) mahasiswa adalah setiap orang yang secara resmi terdaftar untuk mengikuti pelajaran di perguruan tinggi dengan batas usia sekitar 18-30 tahun. Dari kedua pengertian tersebut jelaslah mahasiswa adalah pemuda yang sedang menimba ilmu di perguruan tinggi.

Kesatuan Aksi Mahasiswa Muslim Indonesia (KAMMI) adalah salah satu organisasi ekstra kampus. Kesatuan Aksi Mahasiswa Muslim Indonesia (KAMMI) merupakan sebuah pergerakan mahasiswa yang lahir di era reformasi tentunya mempunyai peran dan tanggung jawab sebagai mahasiswa dan pemuda dalam perjalanan bangsa kedepannya. KAMMI yang mempunyai visi dan misi ingin melahirkan pemimpin masa depan yang tangguh diharapkan mampu menghasilkan sumber daya manusia yang baik secara intelektual dan tingkat wawasan juga mempunyai fisik yang tangguh dan kuat dalam upaya menghadapi persoalan persoalan yang semakin rumit di tengah masyarakat bangsa dan negara.

\section{METODE PENELITIAN}

Penelitian ini dilakukan di Kesatuan Aksi Mahasiswa Muslim Indonesia Kota Medan dengan pertimbangan bahwa Kesatuan Aksi Mahasiswa Muslim Indonesia Kota Medan belum memiliki strategi secara khusus menghadapi Era Mayarakat Ekonomi Asean. Penelitian ini dimulai pada bulan Juli 2016 sampai dengan September 2016. Jenis penelitian ini adalah penelitian kualitatif perspektif fenomenologi sosial yang dimaksudkan untuk mengungkapkan secara rinci 
fenomena kesiapan Kesatuan Aksi Mahasiswa Muslim Indonesia Kota Medan dan tantangannya terhadap MEA.

Informan dalam penelitian ini adalah informan yang dipilih mengacu pada prinsip kesesuaian (appropriatness) dan kecukupan (adequacy), yaitu orang-orang yang memiliki keterkaitan dengan ruang gerak Kesatuan Aksi Mahasiswa Muslim Indonesia Kota Medan. Informan dari internal Kesatuan Aksi Mahasiswa Muslim Indonesia Kota Medan yang dipilih adalah; Ketua Umum Kesatuan Aksi Mahasiswa Muslim Indonesia Kota Medan 1 orang, wakil ketua Kesatuan Aksi Mahasiswa Muslim Indonesia Kota Medan 1 orang, Ketua Bidang Kaderisasi Kesatuan Aksi Mahasiswa Muslim Indonesia Kota Medan 1 orang, ketua Komisariat Kesatuan Aksi Mahasiswa Muslim Indonesia Se-Kota Medan 13 Orang, Bendahara Kesatuan Aksi Mahasiswa Muslim Indonesia Kota Medan 1 orang, Bidang Ekonomi Kesatuan Aksi Mahasiswa Muslim Indonesia Kota Medan 2 orang, sehingga jumlah informan sebanyak 16 orang. Sedangkan informan eksternal adalah mewakili unsur Dinas Pemuda dan Olahraga 1 orang, mewakili KNPI 1 Orang, mewakili mahasiwa umum di masing masing kampus 1 Orang jumlahnya 15 0rang.

Jenis data yang dikumpulkan dalam penelitian ini adalah berupa data primer dan data sekunder. Data primer adalah data yang diperoleh langsung dari informan melalui wawancara mendalam (indepth interview) berupa informasi, kata-kata atau tindakan yang diperoleh melalui observasi dan wawancara. Sedangkan data sekunder adalah data yang diperoleh berupa bentuk laporan untuk melengkapi data primer.

Instrumen yang digunakan dalam penelitian ini adalah berupa pedoman wawancara menggunakan alat perekam (tape recorder) dan kamera. Pedoman wawancara digunakan sebagai acuan untuk menggali informasi melalui wawancara mendalam.

Teknik pengumpulan data yang digunakan dalam penelitian ini adalah:

a. Wawancara

Memperoleh informasi dari informan,peneliti akan melakukan wawancara 
mendalam terhadap informan yang terpilih Kesatuan Aksi Mahasiswa Muslim Indonesia Kota Medan, dengan tujuan agar memperoleh informasi yang lebih rinci dan mendalam menggunakan pedoman wawancara terhadap informan dan dilakukan oleh peneliti sendiri.

b. Observasi ( pengamatan)

Dalam penelitian ini salah satu teknik pengumpulan data dilakukan melalui pengamatan, yaitu peneliti secara langsung mengamati jalannya kegiatan operasional Kesatuan Aksi Mahasiswa Muslim Indonesia Kota Medan.

Penelitian ini merupakan penelitian objektif terhadap data yang diperoleh di lapangan. Data ini diperlakukan sebagaimana adanya, tanpa dikurangi, ditambahi ataupun diubah, sehingga tidak akan mempengaruhi keaslian data-data tersebut. Keseluruhan data yang diperoleh dari hasil penelitian lapangan tersebut akan diteliti kembali, pada akhirnya kegiatan ini bertujuan untuk memeriksa kembali kelengkapan hasil wawancara. Langkah selanjutnya, data-data yang telah tersedia dan telah diteliti kembali ini akan dianalisis secara kualitatif. Keseluruhan data yang diperoleh dari observasi, wawancara dan sumber kepustakaan disusun berdasarkan pemahaman-pemahaman akan fokus penelitian atau berdasarkan kategori yang sesuai dengan tujuan peneliti.

\section{HASIL PENELITIAN DAN PEMBAHASAN}

Masyarakat Ekonomi ASEAN (MEA) 2015 (bahasa Inggris: ASEAN Economic Community (AEC)) adalah sebuah integrasi ekonomi ASEAN dalam menghadapi perdagangan bebas antarnegara-negara ASEAN. Seluruh negara anggota ASEAN telah menyepakati perjanjian ini. MEA dirancang untuk mewujudkan Wawasan ASEAN 2020.

MEA merupakan singkatan dari Masyarakat Ekonomi ASEAN yang memiliki pola mengintegrasikan ekonomu ASEAN dengan cara membentuk sistem perdagangan bebas atau free trade antara negara-negara anggota ASEAN. Para anggota ASEAN termasuk Indonesia telah menyepakati suatu perjanjian Masyarakat Ekonomi ASEAN tersebut. MEA adalah istilah yang hadir dalam 
indonesia tapi pada dasarnya MEA itu sama saja dengan AEC atau ASEAN ECONOMIC COMMUNITY.

Awal mula MEA berawal pada KTT yang dilaksanakan di Kuala Lumpur pada tanggal 1997 dimana para pemimpin ASEAN akhirnya memutuskan untuk melakukan pengubahan ASEAN dengan menjadi suatu kawasan makmur, stabil dan sangat bersaing dalam perkembangan ekonomi yang berlaku adil dan dapat mengurangi kesenjangan dan kemiskinan sosial ekonomi (ASEAN Vision 2020). kemudian dilanjutkan pada KTT bali yang terjadi pada bulan Oktober pada tahun 2003, para pemimpin ASEAN mengaluarkan pernyataan bahwa Masyarakat Ekonomi ASEAN atau MEA akan menjadi sebuah tujuan dari perilaku integrasi ekonomi regional di tahun 2020, ASEA SECURITY COMMUNITY dan beberapa komunitas sosial Budaya ASEAN merupakan dua pilar yang tidak bisa terpisahkan dari komunitas ASEA. Seluruh pihak diharapkan agar dapat bekerja sama secara kuat didalam membangun komunitas ASEAN di tahun 2020.

\section{Ciri Ciri dan Unsur Masyarakat Ekonomi Asean}

MEA atau Masyarakat Ekonomi ASEAN ialah suatu realisasi dari tujuan akhir terhadap integrasi ekonomi yang telah dianut didalam ASEAN Visi 2020 yang berdasarkan atas konvergensi kepentingan para negara-negara anggota ASEAN untuk dapat memperluas dan memperdalam integrasi ekonomi lewat inisiatif yang ada dan baru dengan memiliki batas waktu yang jelas. Didalammendirikan masyarakat ekonomi ASEAN atau MEA, ASEAN mesti melakukan tidakan sesuai dengan pada prinsip-prinsip terbuka, berorientasi untuk mengarah ke luar, terbuka, dan mengarah pada pasar ekonomi yang teguh pendirian dengan peraturan multilateral serta patuh terhadap sistem untuk pelaksanaan dan kepatuhan komitmen ekonomi yang efektif berdasarkan aturan.

MEA akan mulai membentuk ASEAN menjadi pasar dan basis dari produksi tunggal yang dapat membuat ASEAN terlihat dinamis dan dapat bersaing dengan adanya mekanisme dan langkah-langkah dalam memperkuat pelaksanaan baru yang berinisiatif ekonomi; mempercepat perpaduan regional yang ada disektor-sektor prioritas; memberikan fasilitas terhadap gerakan bisnis, tenaga kerja memiliki bakat dan terampil; dapat memperkuat kelembagaan 
mekanisme di ASEAn. Menjadi langkah awal dalam mewujudkan MEA atau MAsyarakat Ekonomi ASEAN.

Disaat yang sama, MEA akan dapat mengatasi kesenjangan pada pembangunan dan melakukan percepatan integrasi kepada negara Laos, Myanmar, VIetnam dan Kamboja lewat Initiative for ASEAN integration dan inisiatif dari regional yang lainnya. Adapun bentuk kerjasamanya ialah

a. Pengembangan pada sumber daya manusia dan adanya peningkatan kapasitas

b. Pengakuan terkait kualifikasi professional

c. Konsultasi yang lebih dekat terhadap kebijakan makro keuangan dan ekonomi.

d. Memilik langkah-langkah dalam pembiayaan perdagangan.

e. Meningkatkan infrastruktur.

f. Melakukan pengembangan pada transaksi elektronik lewat e-ASEAN.

g. Memperpadukan segala industri yang ada diseluruh wilayah untuk dapat mempromosikan sumber daerah.

h. Meningkatkan peran dari sektor swasta untuk dapat membangun MEA atau Masyarakat Ekonomi ASEAN.

Ciri-ciri ini akan sangat saling berkaitan dengan kuat. Dengan memasukkan pada unsur-unsur yang paling dibutuhkan dari setiap masing-masing ciri-ciri dan mesti dapat memastikan untuk konsisten dan adanya keterpaduan dari unsur-unsur dan pelaksanaannya yang tepat dan bisa saling mengkoordinasi antara para pemangku kekuasaan atau kepentingan yang punya relevansi.

\section{Kesiapan MEA di Beberapa Negara ASEAN}

Sejak kebijakan Masyarakat Ekonomi ASEAN (MEA) dicetuskan, Indonesia mulai sibuk berbenah untuk siap menghadapinya. Tidak hanya Indonesia, sembilan negara Asean lainnya juga turut mempersiapkan diri untuk 
menyambut era perdagangan bebas ini. Mari kita intip, sudah sejauh apa persiapan negara-negara demi menghadapi MEA.

MEA adalah bentuk sistem perdagangan bebas antar negara-negara asean. Indonesia dan sembilan negara anggota ASEAN lainnya telah menyepakati untuk mempercepat pelaksanaan MEA pada tahun 2015. Bagaimana persiapan negara mereka?

Di Filipina, masyarakatnya kini tengah bersiap menjadikan MEA sebagai cara baru untuk meningkatkan kesejahteraan hidup dengan merantau ke negaranegara tetangga. Tentu saja, Filipina melengkapi tenaga kerjanya dengan sertifikasi yang mumpuni baik di wilayah regional atau global. Pemerintah negeri itu tampak serius menggarap berbagai jalur pendidikan, baik formal maupun nonformal. Tujuannya apalagi kalau bukan untuk memastikan warga negaranya dapat diterima bekerja di luar negeri, dalam masa MEA.

Malaysia juga melakukan hal yang sama. Negeri jiran ini rutin melakukan uji kompetensi sebagai langkah persiapan tenaga kerja lokal untuk bersaing di kancah regional. Bahkan, para investor perbankan tengah bersiap melebarkan sayapnya di beberapa negara tetangga, termasuk di Indonesia.

Tidak mau ketinggalan, Thailand sendiri sudah mulai mempekuat sektor di bidang kesehatan, pariwisata, hotel dan restoran, sehingga pendapatan Thailand dari luar negeri meningkat. Mengantisipasi terhadap MEA, Negeri Gajah Putih memperluas wahana investasi yang ada di negeri itu, mulai properti, hasilhasil bumi, hingga potensi wisata lokal. Tak hanya itu, kini penggunaan bahasa Inggris, bahkan di salah satu pusat pelatihan di Thailand juga ada pelajaran Bahasa Indonesia.

Saat ini, sebagian besar perusahaan UKM di Vietnam sedang gencar melakukan promosi ke negara-negara lain untuk memperkuat sektor ekspor mereka. Vietnam juga sedang menggalakan program sertifikasi bagi para pekerja mudanya. Selain itu, negara ini juga tengah melakukan beberapa hukum terkait UU Investasi, Hukum Dagang, Hukum Bisnis dan mengeluarkan banyak keputusan dan pedoman hukum ini. 
Singapore sendiri tengah sibuk mengembangkan kawasan teknologi mereka. Negeri singa ini adalah negara yang paling ditakuti dan paling maju di kawasan Asean. Walau kecil dengan jumlah penduduk yang kira-kira setengah penduduk Jakarta, namun pada faktanya selama tiga tahun berturut-turut, dari tahun 2010 hingga 2012, Singapura menjadi investor terbesar di Indonesia. Nilai investasi Singapura di Indonesia tahun 2012 sebesar 4,9 miliar dolar AS, tahun 2011 sebesar 5,1 miliar dolar AS, dan 2010 sebesar 5,01 dolar AS.

\section{Kesatuan Aksi Mahasiswa Muslim Indonesia Kota Medan}

Setelah Kesatuan Aksi Mahasiswa Muslim Indonesia (KAMMI) di deklarasikan Di Malang maka tidak lama kemudian di deklarasikan di Kota Medan. Namun pada saat itu KAMMI lahir masih dalam tingkat wilayah atau provinsi. Perjalanan KAMMI sendiri khususnya di Kota Medan cukup diterima di kalangan intelektual muda yaitu mahasiswa. Kampus kampus besar yang ada di Medan menjadi basis pergerakan KAMMI. Mulai tahun 2000 KAMMI Daerah Sumatera Utara sudah memiliki cabang di kampus yang ada di Kota Medan seperti Universitas Sumatera Utara (USU), Universitas Negeri Medan dan Universitas Islam Negeri (UIN), Universitas Medan Arean (UMA), Universitas Islam Sumatera Utara (UISU), Universitas Muslim Nusantara (UMN), Universitas Muhammadiyah Sumatera Utara (UMSU), Institut Teknologi Medan (ITM) dan Jaringan kampus yang ada di Siantar dan Sidempuan.

Kemudian mulai tahun 2011 KAMMI Daerah Sumatera Utara melakukan pemekaran menjadi dua daerah yaitu KAMMI Daerah Kota Medan dan KAMMI Daerah Bukit Barisan. Pemekaran ini bertujuan agar KAMMI Daerah Sumatera Utara yang memiliki ruang kerja yang luas dan terlalu banyak di persempit agar lebih fokus dalam program kerja dan pembinaan. Tercatat Mulai tahun 2011 hingga tahun 2015 sekarang KAMMI Kota Medan sudah mengalami 2 periode kepengurusan dimana setiap periodenya memilki masa bakti selama 2 tahun.

\section{Kegiatan KAMMI Kota Medan}

Sebagai sebuah organisasi kepemudaan sudah menjadi kwajiban bagi KAMMI kota Medan melakukan pengembangan skill bagi para kadernya. Hal ini 


\section{JURNAL PEMBERDAYAAN MASYARAKAT 194 \\ Volume 7 No. 2 Tahun 2019 ISSN: 2355-8679}

dibuktikan dengan berbagai kegiatan yang pernah dilakukan . KAMMI yang selama ini identik dengan aksi, ternyata memiliki sisi lain dibalik ketegasan yang mereka lakukan terhadap isu terkini. Sisi lain itulah sisi pengembangan diri.

Selama ini KAMMI sangat identik dengan sebuah organisasi yang kerap melakukan aksi. Hal ini sesuai dengan kepanjangan dari KAMMI itu sendiri yang merupakan kesatuan aksi. Untuk itu KAMMI kerap diidentikan dengan sebuha gerakan yang fokus kepada aksi demonstrasi di Kota Medan. Namun seiirng berjalannya waktu makna "aksi” bagi KAMMI juga semakin luas. Hal ini terlihat dari bagaimana mereka mengartikan aksi itu sendiri.

Identitas KAMMI selama ini sudah dianggap sebagai organisasi yang banyak konsen melakukan aksi di kota medan. Sebut saja hari anti korupsi, hingga aksi-aksi terkait isu yang tengah berkembang baik di sumatera utara maupun indonesia. Namun kalau ini terus dibiarkan gak bagus juga, karena akan mencedrai tujuan KAMMI itu sendiri. Makanya KAMMI Medan tidak hanya menggelar aksi namun manajemen aksi hingga penguatan kapasistas kader hingga pengabdian juga kami lakukan.

Aksi bagi kesatuan aksi mahasiswa muslim indonesia (KAMMI) Kota Medan menjadi sebuah rangkaian pengabdian bagi mereka. Menegakkan amal ma'ruf nahi munkar sesuai dengan tujuan KAMMI. Untuk mewujudkan hal tersebut tidak dapat hanay dilakukan dengan aksi-aksi demonstrasi ke kantor DPRD, Gubsu dan lain sebagainya. Pengembangan jati diri dan kualitas kader juga menjadi agenda KAMMI untuk menunjukkan betapa luasnya makna aksi tersebut.Berikut ini adalah kegiatan yang dilakukan oleh KAMMI Kota Medan baik yang sifatnya terbuka mapun bersifat tertutup untuk para kader:

1. Training kepemimpinan

Training kepemimpinan memiliki urgensi untuk menghasilkan kadrerkader yang cakap dan berintegritas. Hal ini tentu akan berguna bagi KAMMI dalam menentukan calon-calon pemimpin KAMMI di masa depan. Lebih jauh 
lagi training kepemimpinan mampu mencetak sifat-sifat kader yang mampu memimpin tidak hanya di luar KAMMI tapi dapat juga menjadi pioner peruba kegiataan di masyarakat.

\section{Training Pengembangan Diri}

Demi menghasilkan kader yang tidak hanya mengerti tentang aksi dan agenda dakwah saja, maka KAMMI tidak ingin berhenti pada peningkatan kapasitas dalam training kepemimpinan yang hadir lewat Daurah Marhalah. KAMMI yakin sebuah kecakapan akan berjalan lurus dengan kapasitas dan pengembangan diri seseorang.

3. Training Kewirausahaan

Training kewirausahaan adalah sebuah kegiatan yang dilakukan KAMMI medan untuk menyiapkan kader yang tidak hanya mampu menjadi seorang pemimpin ataupun da'i, namun juga mampu menjadi seorang usahawan. Hal ini adalah usaha yang tengah dirintis oleh KAMMI Medan melihat peluang usaha yang tengah berkembang dewasa ini. Buat pasca lulus menjadi sarjana. Dengan kata lain KAMMI medan memberikan alternatif berbeda kepada kadernya untuk memiliki kemampuan berwirausaha.

Training ini menghadirkan seorang motivator atapun pelaku usaha yang tengah malang melintang di dunia usaha. Hal ini bertujuan untuk mentransfer minat para kader untuk memilki usaha secepat mungkin. Beberapa memberikan motivasi bahwa modal bukan menjadi masalah krusial dalam usaha. Masalah yang terbesar adalah niat untuk memulai.

"Sebenarnya ini bukan tuntutan dari KAMMI agar kader
memiliki usaha. Namun tuntutan zaman yang terus
berubah dimana banyaknya lulusan universitas yang
menganggur menjadi alasan bagi KAMMI untuk
memikirkan harus ada soft skill yang dimiliki kader untuk
menghadapi tantangan zaman".


Kondisi ekonomi Indonesia yang serba tidak stabil juga menjadi acuan bagaimana urgensi KAMMI melakukan training kewiraushaan. Soft skill ini penting agar kader KAMMI mampu berbicara di masyarakat. Hal ini juga mberguna sebagai sarana untuk Melatih agar para kader KAMMI setelah pasca kampus tidak hanya mencari pekerjaan tetapi juga mampu membuka lapangan pekerjaan.

\section{Training Kehumasan}

Training kehumasan dilaksanakan untuk melatih agar para kader KAMMI untuk bisa menulis artikel, mampu berkomunikasi dengan baik, berpidato dan berceramah dengan benar. Hal ini juga merupakan penerapan soft skill bagi kader KAMMI untuk menghadapi tantangan.

"Hal ini sering dianggap remeh oleh para kader KAMMI, tapi training kehumasan itu penting. Hal ini berkaitan dengan bagaimana berkomunikasi yang baik. Misalnya saja ketika orasi di suatu aksi, jika kader KAMMI tidak memiliki tekhnik komunikasi yang baik, maka informasi ataupun tuntutan tersebut akan susah sampai, atau tidak sampai, dan gagal menobarkan semangat selama aksi berlangsung. Hal ini sangat penting bagi keberlangsungan organisasi ini”.

\section{Workshop dan Seminar}

Kegiatan workshop dan seminar adalah kegiatan yang bersifat tentatif atau kegiatan pendukung. Kegiatan ini diselenggarakan dengan mengundang para pakar dan tokoh yang menguasai di bidangnya dan mengundang para mahasiwa yang bukan kader KAMMI.

Kegiatan ini bersifat terbuka bagi seluruh civitas akademika tempat KAMMI berada. Hal ini dimaksudkan untuk memperkenalkan KAMMI, serta mengajak mahasiswa untuk memikirkan topik atau isu yang tengah hangat. 


\section{Bakti Sosial dan Desa Binaan}

Kegiatan bakti sosial dan desa binaan adalah kegiatan yang merupakan wujug pengabdian KAMMI terhadap masyarakat. KAMMI sadar keberadaan mereka sebagai organisasi tidak hanya mencapai tujuan organisasi namun juga menjadi sebuah gerakan yang berguna bagi masyarakat. Salah satu kegiatan yang bisa mereka lakukan adalah dengan melakukan bakti sosial dan pembinaan di sebuah desa.

\section{Tantangan MEA bagi KAMMI Kota Medan}

Peningkatan Kualitas Sumberdaya Manusia, dalam hal pembangunan nasional, adalah pembangunan manusia yang seutuhnya, kemampuan professional dan kematangan pribadi saling yang memperkuat satu sama lain. Profesionalisme dapat turut membentuk sikap dan perilaku serta kepribadian yang tangguh merupakan prasayarat dalam membentuk Kualitas Sumberdaya Manusia Ynga tangguh..

Menurut Mulyadi S (2003) minimal ada empat kebijaksaan pokok dalam upaya peningkatan sumber daya manusia (sdm), yaitu

1. Peningkatan kualitas hidup yang meliputi baik kualitas manusia nya seperti jasmani, rohani dan kejuangan maupun kualitas kehidupannya seperti perumahan dan pemukiman yang sehat

2. Peningkatan kualitas sumber daya manusia yang produktif dan upaya pemerataan penyebarannya.

3. Peningkatan kualitas sumber daya manusia yang berkemampuan dalam memanfaatkan, mengembangkan dan menguasai iptek yang berwawasan lingkungan

4. Pengembanagan pranata yang meliputi kelembagaan dan perangkat hukum yang mendukung upaya peningkatan kualitas sumber daya manusia.

Secara operasiaonal upaya peningkatan kualitas sumber daya manusia dilaksanakan melalui berbagai sektor pembangunan antara lain sektor pendidikan, 
kesehatan, kesejahteraan sosial, kependudukan, tenaga kerja dan sektor sektor lainnya.

Berbicara peningkatan sumber daya manusia adalah peningkatan fisik dan non fisik. Fisik ini yang dimaksud adalah tingkat kesehatannya. Peran apa saja yang telah dilakukan KAMMI sebagai gerakan pemuda dan mahasiswa dalam meningkatkan kualitas kesehatannya. Sedangkan Aspek Non fisik disini adalah meningkatnya kualitas pemuda dalam hal ilmu pengetahuan, peningkatan skill dan peningkatan kualitas secara mental.

\section{Perangkat Organisasi KAMMI dalam Rangka Meningkatkan Minat Kewirausahaan dalam Menghadapi MEA}

Peran pemuda KAMMI dalam menghadapi MEA (Masyarakat Ekonomi ASEAN) yang ditawarkan adalah sebagai berikut:

1. Mensosialisasikan MEA kepada seluruh rakyat Indonesia, karena informasi MEA belum diketahui oleh semua masyarakat Indonesia, terkhusus masyarakat Sumatera Utara, dengan cara mengadakan seminar tentang Masyarakat Ekonomi ASEAN atau biasa disingkat dengan MEA, selain itu publikasi yang bisa digunakan untuk menggencarkan informasi melalui media sosial, seperti facebook, twitter, path, instagram, line, tumbler, whatsapp, $B B M$, dan sebagainya.

2. Penanaman dan pengembangan jiwa kewirausahaan (entrepreneur skill) dengan cara mengadakan pelatihan-pelatihan kewirausahan yang menarik masyarakat di Sumatera Utara dengan mengundang tokoh-tokoh yang berpengaruh di masyarakat dan memiliki keahlian dalam bidangnya.

3. Menanamkan sikap berani, kreatif dan inovatif pada masayarakat Sumatera Utara dengan megadakan perlombaan yang menguntungkan masyarakat sebagai penarik minat masyarakat dengan tujuan menumbuhkan sikap berani, kreatif, dan inovatif dalam diri masayarakat.

4. Melihat produk-produk yang berada di lapangan agar menimbulkan pembelajaran sehingga mampu menghasilkan produk yang inovatif. 
5. Menerapkan prinsip ATM (Amati, Tiru, Modifikasi) pada produk yang telah ada sehingga masyarakat tertarik dengan produk yang diciptakan.

6. Mengikuti lomba karya tulis ilmiah dalam meningkatkan kemampuan dan penalaran dalam bidang wirausaha sehingga mampu bersaing dengan dalam masyarakat ekonomi ASEAN.

7. Menumbuhkan sikap menghargai dan memberikan penghargaan pada setiap produk atau kreatifitas masyarakat.

8. Mendirikan koperasi untuk masyarakat yang membutuhkan dana untuk modal awal perusahaannya dalam upaya mengurangi pengangguran pada masyarakat.

Peran mahasiswa muslim KAMMI yang ditawarkan di atas adalah sebagian dari solusi-solusi yang ada dalam mengahadapi masyarakat ekonomi ASEAN, sehingga disini peran KAMMI sangat dibutuhkan dalam konstelasi persaingan perdagangan bebas di masayarakat ASEAN.

\section{Kesiapan KAMMI Menghadapi MEA}

Keberadaan MEA tentu akan sangat berdampak terhadap kegiatan yang dilakukan KAMMI. Organisasi yang konsen terhadap isu yang tengah berkembang sudah tentu akan menerima dampak kebijakan MEA. Namun hal yang menjadi pertanyaan adalah seberapa jauh kesiapan KAMMI menghadapi MEA.

KAMMI ini organisasi kepemudaan, yang bergerak untuk menjadikan kadernya siap secara fisik mental serta agamanya. Untuk itu banyak kegiatan yang dilakukan KAMMI untuk menunjang hal tersebut. Namun sejauh mana kesiapan KAMMI menghadapi tantangan MEA, kita tak pernah tahu seperti apa.

Sebelumnya telah dijelaskan bagaimana konsentrasi KAMMI dalam meningkatkan kapasistas kadernya dengan berbagai pelatihan dan kegiatan. Kegiatan rutin hingga kegiatan yang bersifat seremonial tidak luput dari pantauan KAMMI. Atas dasar hal tersebut seharusnya KAMMI sebagai organisasi kepemudaan sudah dianggap siap menghadapi tantangan MEA. 
Kenyataan memang terkadang terasa menyakitkan, betapa tidak kegiatan yang dilakukan KAMMI seyogyanya memang menghantarkan kader KAMMI menjadi pribadipribadi yang siap menghadapi MEA. Namun rangkaian evaluasi kegiatan seringkali membuat rasa pesimis itu muncul. Memang kegiatan pengembangan diri dan kegiatan-kegiatan pendukung lainnya sering dilakukan. Namun kegiatan ini tidak memberikan dampak yang besar terhadap perkembangan kader KAMMI. Hal ini misalnya terlihat dari masih minimnya kader KAMMI yang produktif dalam menulis, hingga mereka yang masih malu-malu untuk turun ke dunia usaha. Evaluasi inilah yang membuat saya berpikir bahwa KAMMI belum siap menghadapi tantangan MEA.

Penggalan wawancara di atas menunjukkan rasa pesimstik salah seorang kader KAMMI tentang kesiapan mereka menghadapi MEA. Hal ini berdasrkan evaluasi berbagai macam kegiatan yang seakan tanpa follow up dan dibiarkan mengambang. Ha ini tuntu tidak terlepas dari kegiatan yang dilakukan tanpa keseriusan. Hal ini misalnya terlihat dari training kewirausahaan, dimana para kader diberi motivasi untuk berusaha, namun tidak didukung untuk mempraktekkan atau bimbingan langsung membuat usaha. Hal inilah yang menjadikan kegiatan yang bersifat aplikatif terkesan hanya berupa seremoni saja.

Kegiatan memang banyak, bagus-bagus tapi biasanya kegiatan yangbagus tidak didukung dengan follow up yang benar, hasilnya setelah kegiatan ya tidak ada perubahan. Karena hal yang paling fundamentalis tidak dilakukan yakni “action”.

Action adalah kata yang tepat untuk menggambarkan kesiapan KAMMI menghadapi MEA. KAMMI belum melakukan action terkait kegiatan yang pernah mereka kerjakan. Setiap kegiatan hanya berupa lembaran kertas 
pertanggung jawaban tentang kegiatan yang telah terlaksana dan beberapa kendala yang dihadapi. Kondisi tersebut belum menyentuh tentang tantangan yang MEA hadirkan sendiri bagi KAMMI.

MEA akan masuk kepada sisi yang paling fundamentalis bagi KAMMI yakni tujuan berdirinya organisasi ini. Ibarat sebuah antitesis, MEA seolah menanyakan apakah tujuan KAMMI menjadi relevan terhadap kondisi yang berubah.

Sebenarnya bukan MEA yang bertanya apakah KAMMI akan menjadi layak di eranya. Tapi lebih sebagai evaluasi bagaimana KAMMI mampu memberi warna terhadap kondisi yang dibawa MEA. Apakah tujuan KAMMI masih relevan atau harus ada yang diperbaharui di era MEA sendiri.

Pertanyaan ini menjadi titik yang memberikan efek kejut agar KAMMI mampu mengembangkan diri. Hal ini bukan sebagai ancaman, namun sebagai sebuah motivasi agar KAMMI lebih serius dalam melakukan gerakan. Tidak cukup hanya menjadi sosok yang mampu berbicara tegas, namun juga mempunyai solusi serta ikut dalam percaturan di era MEA.

Terdapat sebuah kekhawatiran bahwa MEA akan merubah suhu ataupun kondisi yang selama ini terbangun di KAMMI. Ada kekhawatiran, bahwa ajakan untuk bersaing di era MEA akan melupakan tujuan KAMMI sebagai bagian dari poltik ekstraparlementer. KAMMI akan kehilangan jati dirinya ketika turun langsung menghadapi MEA. Namun kekhawatiran tersebut harusnya mampu diatasi dengan melakukan revitalisasi tujuan tanpa harus mengobarbnkan ideologi yang sudah lama terbangun. Hal ini akan menjadikan KAMMI lebih tangguh dalam menghadapi MEA.

\section{KESIMPULAN}

Bagian dari akhir sebuah perjalanan akan menghantarkan seseorang pada titik perhentian. Penelitian ini juga akan menghantarkan peneliti untuk mengakhirinya dalam sebuah kesimpulan dan saran. Hal ini sekaligus 
membuktikan bahwa penelitian ini memiliki masalah, dan setiap permasalahan akan berakhir ketika sudah memiliki jawaban.

Kesimpulan dalam penelitian ini berarti menjawab rumusan masalah yang menjadi pokok mengapa penelitian ini layak dilakukan. Peratnayaan penelitian ini adalah bagaimana Kesiapan Kesatuan Aksi Mahasiswa Muslim Indonesia (KAMMI) dalam menghadapi Era Masyarakat Ekonomi Asean di Kota Medan?. Menjawab pertanyaan tersebut dilihat dari bagaimana bentuk kegiatan yang KAMMI lakukan selama ini.

Sebelum era MEA, KAMMI secara rutin melakukan kegiatan pengembangan diri dan peningkatan kapasitas kader. Namun secara khsus menghadapi tantangan MEA, kami belum memiliki program yang secara langsung. Hal ini terbukti dari berbagai macam kegiatan yang dilakukan masih berupa peningkatan kapasitas secara umum. Kondisi ini dilatarbelakangi oleh MEA yang ganungnya belum begitu kuat di Smatera Utara. Hal ini secara tidak langsung membuat KAMMI tidak memilik program khusus menghadapi MEA.

Gaung MEA yang tidak begitu terlihat di Sumatera Utara tidak berarti membuat KAMMI berdiam diri. Bagi KAMMI Medan, MEA ibarat sebuah bom waktu yang siap meledak apabila tidak dipersiapkan. Untuk itu KAMMI tetap bersiap untuk menghadapi tantangan MEA yang pasti datang.

Dari hasil Penelitina yang dilakukan Penulis menympulkan bahwa dalam hal ini Kesatuan Aksi Mahasiswa Muslim Indonesia Kodta Medan Belum Sepenuhnya siap dalam menghadapi era Masyarakat Ekonomi Asean.

Persiapan KAMMI menghadapi MEA dilakukan harusnya dilakukakn dengan mengevaluasi kegiatan yang pernah mereka lakukan. Kegiatan-kegiatan yang bersifat pengembangan diri terutama dalam hal pengembangan skill dan kewirausahaan harus menjadi titik fokus. Hal ini dapat dilakukan dengan memberikan follow up terhadap kegiatan pengembangan dilri yang sudah dilakukan tersebut. Seperti memberikan pengembangan usaha bagi para kader, ataupun memberikan fasilitas bagi kader yang ingin mengembangkan bakat menulis seperti klub menulis ataupun media. 


\section{SARAN}

Setiap penelitian yang berakhir pada sebuah kesimpulan tentu memiliki saran yang mendukung. Saran ini bisa menjadi saran terhadap pengembangan yang ada di dalam penelitian, ataupu saran tentang perbaikan kedepannya. Adapun saran dari penelitian ini bertolak dari kesimpulan yang telah hadir.

Saran yang peneliti berikan tentang kesiapan KAMMI menghadapi MEA adalah dengan memfokuskan diri terhadap penguatan kapasistas kader. Kesiapan diri, mental serta ketrampilan harus dikedepankan. hal ini tentu baik untuk kemajuan KAMMI di era MEA.

Selain itu Agar gerakan KAMMI di Kota Medan perlu untuk dapat saling bersinergi dengan Dinas Pemuda dan Olahraga Kota Medan dalam mengatasi permasalahan pemuda yang ada di Kota Medan. KAMMI Kota Medan bisa bersinergi dengan gerakan kepemudaan lainnya dalam hal peningkatan kualitas sumber daya manusia. Pemerintahan Kota Medan khususnya Dinas Pemuda dan Olahraga lebih meningkatkan anggaran pelatihan dan pendidikan non formal agar kualitas pemuda menjadi lebih baik lagi. Hal ini secara tidak labgsung juga akan meningkatkan kualitas KAMMI dalam menghadapi tantangan MEA.

\section{DAFTAR PUSTAKA}

Adi Susilo, S. 2013. Sejarah Pemikiran Barat. Raja Grafindo Persada. Jakarta.

Ahmadi, A. 1982. Psikologi Sosial. PT. Bina Ilmu. Surabaya

Arifin, S. 2007. Integrasi Keuangan dan Moneter di Asia Timur; Peluang dan Tantangan Bagi Indonesia. Gramedia. Jakarta

Istijanto, 2009. Aplikasi Praktis Riset Pemasaran. Gramedia Pustaka Utama. Jakarta

Komarudin. 1994. Ensiklopedia Manajemen. Bumi Aksara. Jakarta

Lubis, CP. 2004. Implementasi Tri Dharma Perguruan Tinggi dalam mendukung disiplin nasional. e-USU Repository. Universitas Sumatera Utara. Medan 
Nassar, JR.. 2010 Globalization \& Terrorism; The Migration of Dreams and Nightmares, 2nd Ed. Rowman and Littlefield. Oxford

Nizar, MA. 2014. Laporan Dampak Asean Economic Community Terhadap Sektor Industri Dan Jasa, Serta Tenaga Kerja Di Indonesia. Jakarta.

Nurhuda, R., Muluk, MRK. dan Prasetyo WY. 2011 .Analisis Ketimpangan Pembangunan. Jurnal Administrasi Publik (JAP). Vol. 1, Nomor 4, Hal. 110-119. Universitas Brawijaya, Malang

Prasetyo, B. 2005. Metode Penelitian Kuantitatif, Teori dan Aplikasi, Jakarta : PT Raja Grafindo Persada.

Schutz, Alfred, 1967, The Phenomenology of The social World, German: Der Sinnhafie Aufbau Der Sozialen.

Sirojuzilam dan Mahalli K. 2010. Regional: Pembangunan, Perencanaan, dan Ekonomi. USU Press. Medan

Situmorang, SH dan Lutfi, M. 2015. Analisis Data "untuk Riset Manajemen dan Bisnis. USU Press. Medan

Soerjono. 2002. Teori Peranan. Bumi Aksara. Jakarta

Sugiyono. 2006. Metode Penelitian Kuantitatif, Kualitatif, dan R \& D. CV. Alfabeta. Bandung

Suharso dan Retnoningsih, A. 2005 .Kamus Bahasa Indonesia. Widya Karya, Semarang.

Syahrul dan Nizar MA, 2000, "Kamus Istilah-istilah Akuntansi", Cetakan Pertama, Citra Harta Prima, Jakarta

Syafaruddin, Pasya, N. dan Mahariah. 2008. Ilmu Pendidikan Islam. Hijri Pustaka Utama. Jakarta 